\title{
The impact of inflammation and cytokine expression of PM2.5 in AML
}

\author{
TINGTING CHEN ${ }^{1}$, JUAN ZHANG ${ }^{1}$, HUI ZENG ${ }^{1}$, YUE ZHANG ${ }^{1}$, YONG ZHANG ${ }^{1}$, \\ XIAOHUAN ZHOU ${ }^{1}$, DONG ZHAO ${ }^{2}$, YINGMEI FENG ${ }^{2}$ and HEBING ZHOU ${ }^{1}$ \\ Departments of ${ }^{1}$ Hematology and ${ }^{2}$ Endocrinology, Beijing Luhe Hospital, \\ Capital Medical University, Beijing 101100, P.R. China
}

Received October 18, 2017; Accepted April 5, 2018

DOI: $10.3892 / \mathrm{ol} .2018 .8965$

\begin{abstract}
Environmental and health issues have become a major focus of research worldwide in recent years. Particulate matter with diameter $\leq 2.5 \mu \mathrm{m}$ (PM2.5) is a common air pollutant that has been demonstrated to be associated with various diseases, including acute myeloid leukemia (AML). In the present study, the effects of PM2.5 on the proliferation and inflammation were assessed using three human acute myeloid cell lines (U937, HL-60 and KG-1a) in vitro. Additionally, the levels of several cytokines [interleukin (IL)-2, IL-10, IL-17A and tumor necrosis factor (TNF) $\alpha$ ] in AML cells and Sprague Dawley rats were evaluated to investigate the effects of PM2.5 on cytokine expression in AML. The results revealed that PM2.5 was capable of enhancing inflammatory responses in AML cells, and increasing $I L-2, I L-10, I L-17 A$ and $T N F \alpha$ mRNA expression in AML cells to different degrees. Furthermore, PM2.5 increased $I L-2$ and $I L-10$ contents in rats following 12 weeks of exposure. These results suggested that PM2.5 may serve a role in promoting the occurrence and progression of leukemia by affecting cytokine expression, and that there may be various mechanisms active in different AML subtypes.
\end{abstract}

\section{Introduction}

Air pollution, also known as smog, has become much more severe in China in recent years. Smog is the result of interactions between specific climatic conditions and human activities. The economic and social activities of high-density populations result in the emission of large amounts of fine particulate matter; one such common pollutant is known as particulate matter with diameter $\leq 2.5 \mu \mathrm{m}$ (PM2.5) due to the

Correspondence to: Dr Hebing Zhou, Department of Hematology, Beijing Luhe Hospital, Capital Medical University, 82 Xinhua South Road, Tongzhou, Beijing 101100, P.R. China

E-mail: zhbyffs@126.com

Key words: PM2.5, acute myeloid leukemia, inflammation, cytokine aerodynamic diameter is $\leq 2.5 \mu \mathrm{m}$. When the discharge of PM2.5 exceeds the circulation and carrying capacity of the atmosphere, these fine particles accumulate in the air, leading to smog. Numerous studies have demonstrated that air pollution damages the respiratory system, cardiovascular system, and organs, including the heart and lungs (1-8) Additionally, PM2.5 increases the incidence of infectious diseases and decreases male fertility (9-13).

Leukemia, a malignant clonal disease originating from hematopoietic stem cells, is a major public health threat, and the sixth and eighth leading cause of cancer-associated mortality in men and women in China, respectively. Notably, leukemia is the leading cause of cancer-associated mortality in children and patients $<35$ years old. In recent years, several studies have demonstrated the association between PM2.5 and the risk of leukemia. Studies by Brosselin and Steffen have revealed that living near gas stations or garages may increase the risk of developing acute lymphoblastic leukemia and acute myeloid leukemia (AML) $(14,15)$. Another study performed in Denmark indicated that there is an association between traffic-associated air pollution and the risk of developing AML (16).

Despite extensive studies, the mechanisms mediating the effects of PM2.5 on the occurrence and development of leukemia remain unclear. However, changes in the bone marrow microenvironment are considered to be involved in the progress of leukemia $(17,18)$. A study performed in Taiyuan, China demonstrated that PM2.5 affects cell proliferation, but does not cause cell injury in exposed leukemia cells and that low doses of PM2.5 accelerates leukemia development through a reactive oxygen species-mediated pathway (19).

In the present study, the effects of various concentrations of PM2.5 on cell proliferation were investigated in three AML cell lines (U937, HL-60 and KG-1a). The expression levels of several cytokines, including interleukin-2 (IL-2), IL-10, IL-17A and tumor necrosis factor (TNF) $\alpha$, after PM2.5 exposure in AML cell lines and rats were also evaluated, with the aim of elucidating the mechanisms through which PM2.5 affects the occurrence and development of leukemia.

\section{Materials and methods}

Reagents and cell lines. PM2.5 particles purchased from the National Institute of Standards and Technology (Gaithersburg, 
MD, USA) were diluted in sterilized PBS solution to $5 \mathrm{mg} / \mathrm{ml}$ and preserved at $-20^{\circ} \mathrm{C}$ in aliquots. The samples were then diluted to a working concentration in RPMI-1640 (cat. no. SH30809.01; Hyclone; GE Healthcare Life Sciences, Logan, UT, USA) prior to use.

Three human AML cell lines (U937, HL-60 and KG-1a) were purchased from the National Infrastructure of Cell Line Resource (Beijing, China). U937 and HL-60 cells were cultured in RPMI-1640 supplemented with $10 \%$ fetal bovine serum (cat. no. 10099141; Gibco; Thermo Fisher Scientific, Inc., Waltham, MA, USA), whereas KG-1a cells were cultured in RPMI-1640 supplemented with $20 \%$ fetal bovine serum. All cell lines were cultured at $37^{\circ} \mathrm{C}$ in a $5 \% \mathrm{CO}_{2}$ humidified atmosphere without antibiotics.

Treatment of U937, HL-60 and KG-1a cell lines. U937, HL-60 and KG-1a cells were treated with PM2.5 solution at concentrations of $0-20 \mathrm{mg} / \mathrm{ml}$ for 24,48 and $72 \mathrm{~h}$ after reaching a steady-state of exponential growth in normal medium.

Measurement of cell proliferation. Cell proliferation rates were measured using a Cell Counting Kit-8 (Dojindo Molecular Technologies, Inc., Kumamoto, Japan) according to the manufacturer's protocol. The relative cell proliferation ratio (\%) following treatment was compared with controls (cultured cells without PM2.5 treatment or blank controls with RPMI-1640 with $10 \% \mathrm{FBS})$, and calculated as follows: $\left[\left(\mathrm{A}_{\text {control }}-\mathrm{A}_{\text {blank of control }}\right)\right.$ $\left.\left(\mathrm{A}_{\text {sample }}-\mathrm{A}_{\text {blank of sample }}\right)\right] /\left(\mathrm{A}_{\text {control }}-\mathrm{A}_{\text {blank of control }}\right) \times 100 \%$.

Measurement of cytokine mRNA expression levels in AML cell lines. The mRNA expression levels of $I L-2, I L-10, I L-17 A$, and $T N F \alpha$ were detected by reverse transcription-quantitative polymerase chain reaction (RT-qPCR) in AML cells following treatment with $0.1 \mathrm{mg} / \mathrm{ml}$ PM2.5 solution for $0,24,48$ and $72 \mathrm{~h}$. The housekeeper gene actin $\beta$ was used as a control. The RNA of cells was extracted using Trizol reagent (cat. no. 15596018; Invitrogen; Thermo Fisher Scientific, Inc.). cDNA templates from AML cell lines were prepared using a TIANScript RT kit (Tiangen Biotech, Co., Ltd., Beijing, China) according to the manufacture's protocol.

RT-qPCR cycling was performed in 96-well plates on a LightCycler 480 Real-Time PCR system (Roche Applied Science, Penzberg, Germany). The reaction was performed in a $20-\mu 1$ total volume containing $10 \mu \mathrm{l}$ SYBR Select Master mix (cat. no. 4472908; Thermo Fisher Scientific, Inc.), $1 \mu 1$ of each primer $(10 \mu \mathrm{M})$, and $2 \mu$ l template cDNA. The primer sequences used for PCR are presented in Table I. The amplification protocol consisted of an initial denaturation step at $95^{\circ} \mathrm{C}$ for $5 \mathrm{~min}$, followed by two-step PCR for 40 cycles at $95^{\circ} \mathrm{C}$ for $30 \mathrm{sec}$ and $60^{\circ} \mathrm{C}$ for $30 \mathrm{sec}$. The mRNA expression levels of each target were determined based on the cycle threshold $(\mathrm{Cq})$ value for the reference and each target and calculated as $2^{-\Delta \mathrm{Cq}}(20)$. Three independent experiments were performed.

Measurement of protein expression levels in rats. All 26 Sprague Dawley (SD) rats were 6-week-old males (173-190 g), purchased from Charles River Laboratories (Beijing, China), and housed at a temperature of $25^{\circ} \mathrm{C}, 1.013 \times 10^{5}$ pa atmosphere, $12 / 12 \mathrm{~h} \mathrm{dark} /$ light cycle and ad libitum access to food and water. The present study was approved by Ethics Committee of
Table I. Primer sequences and lengths of detected genes.

\begin{tabular}{llc}
\hline $\begin{array}{c}\text { Primer } \\
\text { name }\end{array}$ & \multicolumn{1}{c}{$\begin{array}{c}\text { Sequence } \\
\left(5^{\prime}-3^{\prime}\right)\end{array}$} & $\begin{array}{c}\text { Product } \\
\text { length } \\
(\mathrm{bp})\end{array}$ \\
\hline$I L-2$ & F: TACAAGAACCCGAAACTGACTCG & 29 \\
& R: ACATGAAGGTAGTCTCACTGCC & 28 \\
$I L-10$ & F: TCAAGGCGCATGTGAACTCC & 26 \\
& R: GATGTCAAACTCACTCATGGCT & 28 \\
$I L-17 A$ & F: AGATTACTACAACCGATCCACCT & 29 \\
& R: GGGGACAGAGTTCATGTGGTA & 27 \\
$T N F \alpha$ & F: CCTCTCTCTAATCAGCCCTCTG & 28 \\
& R: GAGGACCTGGGAGTAGATGAG & 27 \\
ACTB & F: CATGTACGTTGCTATCCAGGC & 27 \\
& R: CTCCTTAATGTCACGCACGAT & 27 \\
\hline
\end{tabular}

$\mathrm{IL}$, interleukin; TNF, tumor necrosis factor; $\mathrm{ACTB}$, actin $\beta$; F, forward; $\mathrm{R}$, reverse.

Beijing Luhe Hospital Affiliated to Capital Medical University (Beijing, China). Exposed chambers and clean chambers were constructed to raise rats. Air in the exposed chambers was the same as the true air outside, whereas air in the clean chambers was filtered to remove PM2.5 particles. Fourteen rats were kept in exposed chambers $(n=8)$ or clean chambers $(n=6)$ for 6 weeks (between August 9, 2016 and September 19, 2016), and 12 rats were kept in exposed chambers $(n=8)$ or clean chambers $(n=4)$ for 12 weeks (between August 9, 2016 and October 10, 2016). The PM2.5 concentration in the atmosphere during the study is presented in Table II.

The peripheral blood of rats was collected from hearts after feeding for 6 or 12 weeks. Blood samples were centrifuged at $1,000 \mathrm{x} \mathrm{g}$ for $20 \mathrm{~min}$ at room temperature to obtain serum. Milliplex Map Rat Cytokine/Chemokine Magnetic Bead Panel-Immunology Multiplex assays (cat. no. RECYTMAG-65K; EMD Millipore, Billerica, MA, USA) were used to detect the expression of cytokines in serum according to the manufacturer's protocol.

Statistical analysis. Statistical analysis was performed using Microsoft Excel 2010 (Microsoft Corporation, Redmond, WA, USA) and Graphpad Prism 5 (GraphPad Software, Inc., La Jolla, CA, USA). All data were derived from at least three independent experiments and are presented as means \pm standard deviations. The results were evaluated using two-tailed unpaired Student's t-test and one-way analysis of variance (ANOVA) with Dunnett's multiple comparison post-hoc test. $\mathrm{P}<0.05$ was considered to indicate a statistically significant difference. In RT-qPCR analysis, statistical significance was assumed if the $2^{-\Delta \mathrm{ct} \text { (target mean value-reference mean value) }}$ value was $>150 \%$ or $<75 \%$.

\section{Results}

Low concentrations of PM2.5 promote proliferation, whereas high concentrations of PM2.5 inhibit proliferation in AML cells. First, the effects of PM2.5 on the proliferation of AML 

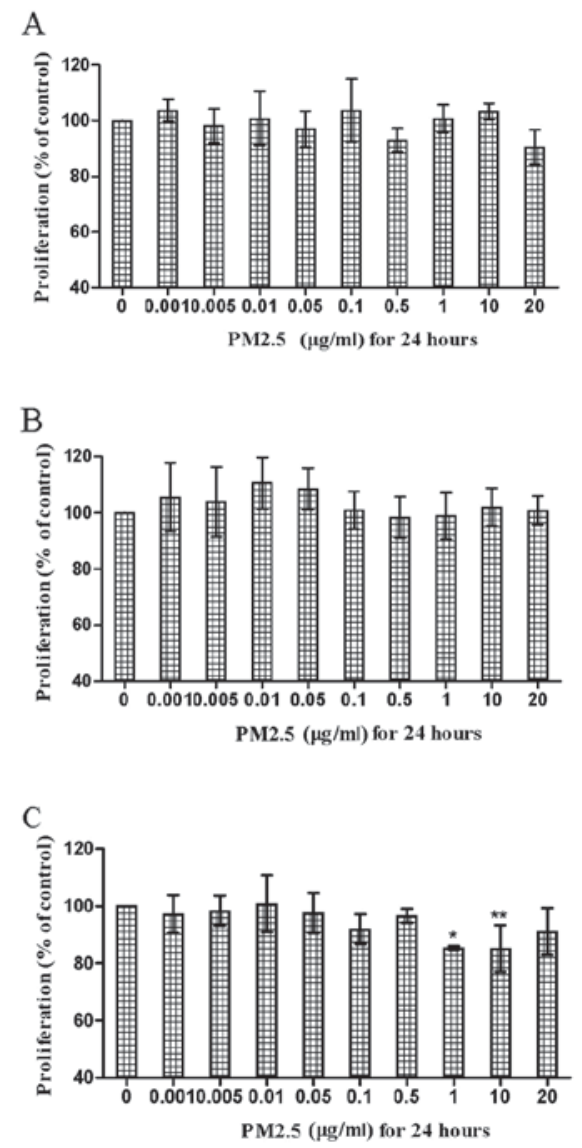
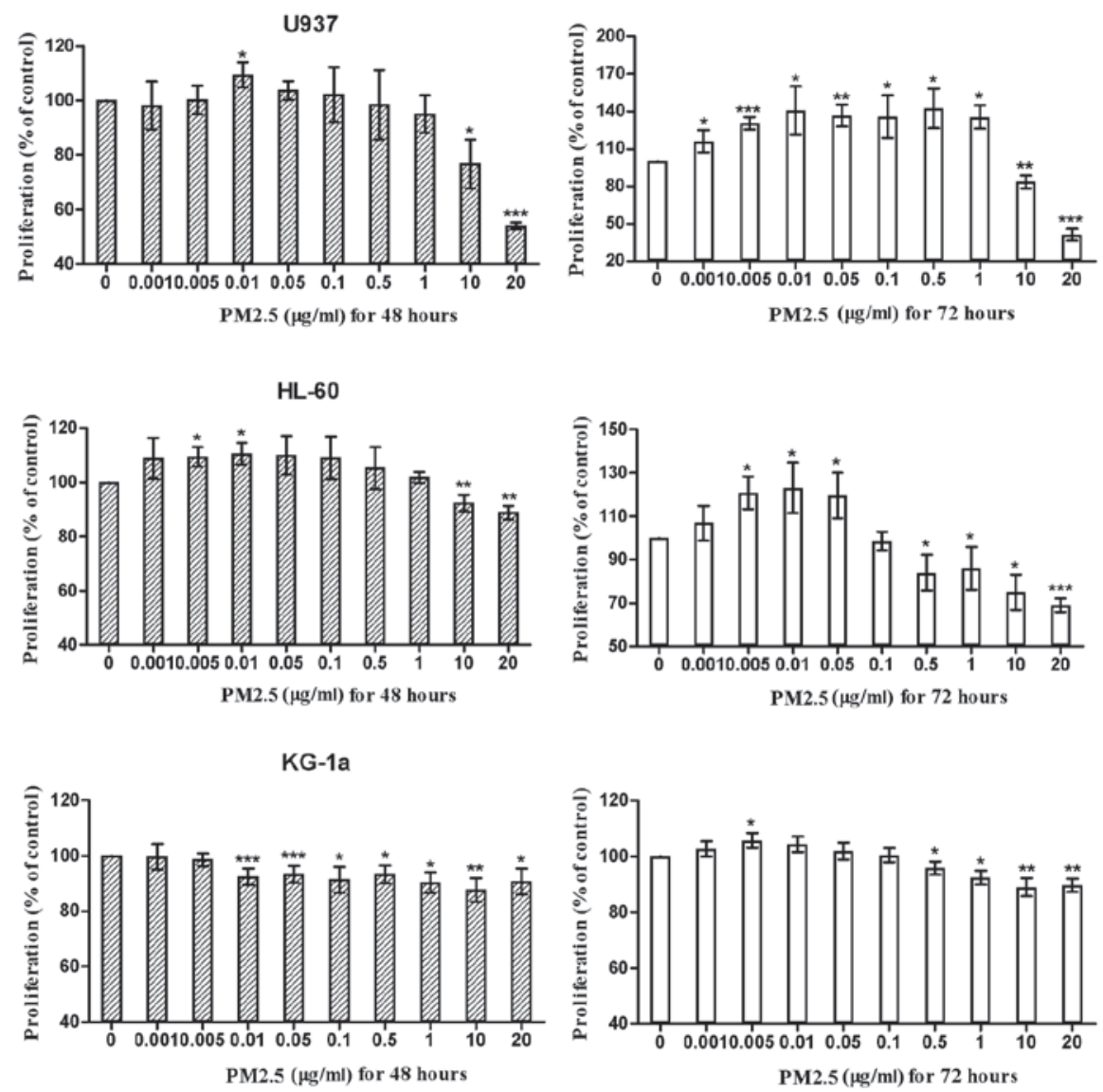

Figure 1. Stimulatory and inhibitory effects of PM2.5 on cell proliferation in (A) U937, (B) HL-60 and (C) KG-1a cells. Cells were treated with different concentrations of PM2.5 for 24,48 , or $72 \mathrm{~h}$. Values represent the means \pm standard deviations of three identical experiments with four replicates each. ${ }^{*}<0.05$, ${ }^{* *} \mathrm{P}<0.005,{ }^{* * *} \mathrm{P}<0.0005$ vs. $0 \mu \mathrm{g} / \mathrm{ml}$. PM2.5, particulate matter with diameter $\leq 2.5 \mu \mathrm{m}$.

cell lines (U937, HL-60, and KG-1a) were evaluated. The results demonstrated that $24 \mathrm{~h}$ of treatment with PM2.5 did not induce or inhibit the proliferation of U937 cells at any concentration. However, after 48 or $72 \mathrm{~h}$ of treatment, PM2.5 first promoted and then significantly inhibited the proliferation of U937 cells as the concentration of PM2.5 increased. These effects were more evident at $72 \mathrm{~h}$ compared with at $48 \mathrm{~h}$. A similar situation was observed in HL-60 and KG-1a cells. However, the stimulatory and inhibitory effects of PM2.5 on KG-1a cells were less evident compared with those on U937 and HL-60 cells (Fig. 1).

PM2.5 significantly alters the expression of cytokines in $A M L$ cells. Next, the expression levels of $I L-2, I L-10, I L-17 A$ and $T N F \alpha$ were analyzed in U937, HL-60 and KG-1a cells following treatment with PM2.5. The results revealed that the mRNA expression levels of $I L-2$ in U937 cells, $I L-17 A$ in HL-60 cells, and $I L-2$ and $I L-17 A$ in KG-1a cells were below the limit of detection (data not shown). In contrast, the expression of $I L-10, I L-17 A$ and $T N F \alpha$ in U937 cells; $I L-10$ and $T N F \alpha$ in HL-60 cells; and $I L-10$ in KG-1a cells significantly increased in a time- and concentration-dependent manner (Figs. 2 and 3). Notably, $I L-2$ expression in HL-60 cells and $T N F \alpha$ expression in KG-1a also increased after treatment with $0.1 \mu \mathrm{g} / \mathrm{ml}$ PM2 2.5 for $24 \mathrm{~h}$ or $\geq 0.01 \mu \mathrm{g} / \mathrm{ml}$ for $72 \mathrm{~h}$; however, these effects did not persist over time (Fig. 2) and did not increase as the concentration was increased (Fig. 3).
PM2.5 significantly increases serum $I L-2$ and $I L-6$ in $S D$ rats following treatment for 12 weeks. Four cytokines, $I L-2$, $I L-10, I L-17 A$ and $T N F \alpha$, were detected in SD rat serum using enzyme-linked immunosorbent assays following treatment with PM2.5 for 6 or 12 weeks. The results demonstrated that exposure to PM2.5 for 6 weeks did not significantly alter serum levels of $I L-2, I L-10, I L-17 A$ and $T N F \alpha$ in SD rats (Table III). However, when the exposure time was increased to 12 weeks, serum $I L-2$ and $I L-10$ levels in rats were significantly higher compared with those of untreated rats (Table IV).

\section{Discussion}

Several epidemiological studies have demonstrated positive associations between PM2.5 exposure and increased leukemia risk (14-16,21-23). However, the mechanism explaining this association has not yet been elucidated. The present study aimed to explain the effects of PM2.5 on the occurrence and development of leukemia through its influence on cytokines in vitro and in vivo.

In the current study, low doses of PM2.5 promoted the proliferation of AML cells (U937, HL-60, and KG-1a), whereas high doses of PM2.5 resulted in cytotoxicity, thereby inhibiting cell proliferation. Furthermore, PM2.5 exposure resulted in significantly increased levels of $I L-2, I L-10, I L-17 A$ and $T N F \alpha$ in AML cells. Thus, these results suggested that PM2.5 was capable of inducing an inflammatory response in human AML cells. 
Table II. PM2.5 concentration of the atmosphere during the study.

A, PM2.5 concentration between August 092016 and September 192016

\begin{tabular}{|c|c|c|c|c|c|}
\hline Date & PM2.5 $\left(\mu \mathrm{g} / \mathrm{m}^{3}\right)$ within chambers & PM2.5 $\left(\mu \mathrm{g} / \mathrm{m}^{3}\right)$ in Beijing outside & Date & $\operatorname{PM} 2.5\left(\mu \mathrm{g} / \mathrm{m}^{3}\right)$ & Beijing \\
\hline Aug-09-2016 & 30 & 44 & Aug-30-2016 & 25 & 28 \\
\hline Aug-10-2016 & 41 & 82 & Aug-31-2016 & 15 & 16 \\
\hline Aug-11-2016 & 36 & 85 & Sep-01-2016 & 6 & 7 \\
\hline Aug-12-2016 & 23 & 59 & Sep-02-2016 & 8 & 11 \\
\hline Aug-13-2016 & 10 & 21 & Sep-03-2016 & 13 & 18 \\
\hline Aug-14-2016 & 9 & 18 & Sep-04-2016 & 56 & 80 \\
\hline Aug-15-2016 & 15 & 20 & Sep-05-2016 & 25 & 27 \\
\hline Aug-16-2016 & 18 & 22 & Sep-06-2016 & 22 & 17 \\
\hline Aug-17-2016 & 35 & 59 & Sep-07-2016 & 28 & 41 \\
\hline Aug-18-2016 & 38 & 74 & Sep-08-2016 & 17 & 20 \\
\hline Aug-19-2016 & 11 & 17 & Sep-09-2016 & 19 & 17 \\
\hline Aug-20-2016 & 31 & 52 & Sep-10-2016 & 18 & 15 \\
\hline Aug-21-2016 & 40 & 51 & Sep-11-2016 & 28 & 32 \\
\hline Aug-22-2016 & 37 & 51 & Sep-12-2016 & 33 & 31 \\
\hline Aug-23-2016 & 35 & 69 & Sep-13-2016 & 62 & 86 \\
\hline Aug-24-2016 & 41 & 79 & Sep-14-2016 & 66 & 101 \\
\hline Aug-25-2016 & 10 & 19 & Sep-15-2016 & 72 & 69 \\
\hline Aug-26-2016 & 9 & 9 & Sep-16-2016 & 82 & 133 \\
\hline Aug-27-2016 & 12 & 14 & Sep-17-2016 & 28 & 41 \\
\hline Aug-28-2016 & 9 & 10 & Sep-18-2016 & 17 & 22 \\
\hline Aug-29-2016 & 14 & 17 & Sep-19-2016 & 12 & 10 \\
\hline Average value & 44 & 61 & Average value & 44 & 61 \\
\hline
\end{tabular}

B, PM2.5 concentration between September 192016 and October 312016

\begin{tabular}{|c|c|c|c|c|c|}
\hline Date & PM2.5 $\left(\mu \mathrm{g} / \mathrm{m}^{3}\right)$ within chambers & PM2.5 $\left(\mu \mathrm{g} / \mathrm{m}^{3}\right)$ in Beijing outside & Date & $\operatorname{PM} 2.5\left(\mu \mathrm{g} / \mathrm{m}^{3}\right)$ & Beijing \\
\hline Sep-20-2016 & 32 & 18 & Oct-11-2016 & 75 & 116 \\
\hline Sep-21-2016 & 56 & 63 & Oct-12-2016 & 77 & 77 \\
\hline Sep-22-2016 & 73 & 99 & Oct-13-2016 & 148 & 150 \\
\hline Sep-23-2016 & 77 & 121 & Oct-14-2016 & 133 & 241 \\
\hline Sep-24-2016 & 85 & 111 & Oct-15-2016 & 96 & 190 \\
\hline Sep-25-2016 & 80 & 162 & Oct-16-2016 & 83 & 119 \\
\hline Sep-26-2016 & 44 & 58 & Oct-17-2016 & 52 & 59 \\
\hline Sep-27-2016 & 10 & 24 & Oct-18-2016 & 80 & 117 \\
\hline Sep-28-2016 & 20 & 13 & Oct-19-2016 & 130 & 225 \\
\hline Sep-29-2016 & 56 & 51 & Oct-20-2016 & 42 & 94 \\
\hline Sep-30-2016 & 76 & 97 & Oct-21-2016 & 49 & 42 \\
\hline Oct-01-2016 & 106 & 165 & Oct-22-2016 & 23 & 14 \\
\hline Oct-02-2016 & 96 & 183 & Oct-23-2016 & 43 & 26 \\
\hline Oct-03-2016 & 62 & 120 & Oct-24-2016 & 79 & 60 \\
\hline Oct-04-2016 & 37 & 33 & Oct-25-2016 & 87 & 96 \\
\hline Oct-05-2016 & 66 & 55 & Oct-26-2016 & 24 & 43 \\
\hline Oct-06-2016 & 48 & 72 & Oct-27-2016 & 36 & 30 \\
\hline Oct-07-2016 & 35 & 39 & Oct-28-2016 & 17 & 10 \\
\hline Oct-08-2016 & 26 & 11 & Oct-29-2016 & 38 & 23 \\
\hline Oct-09-2016 & 52 & 31 & Oct-30-2016 & 34 & 43 \\
\hline Oct-10-2016 & 88 & 87 & Oct-31-2016 & 10 & 8 \\
\hline Average value & 44 & 61 & Average value & 44 & 61 \\
\hline
\end{tabular}

PM2.5, particulate matter with diameter $\leq 2.5 \mu \mathrm{m}$. 
A

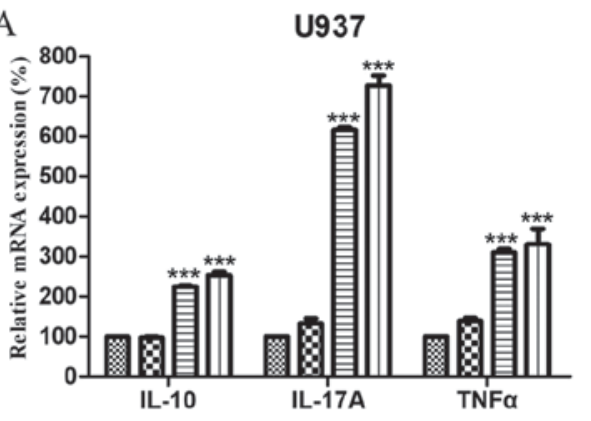

B

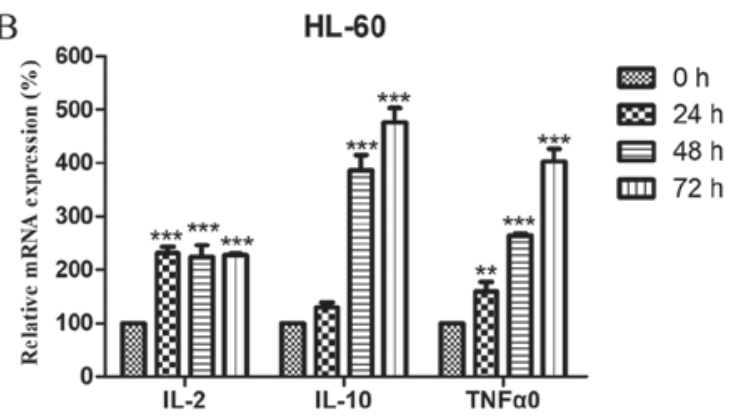

$\mathrm{C}$ KG-1a

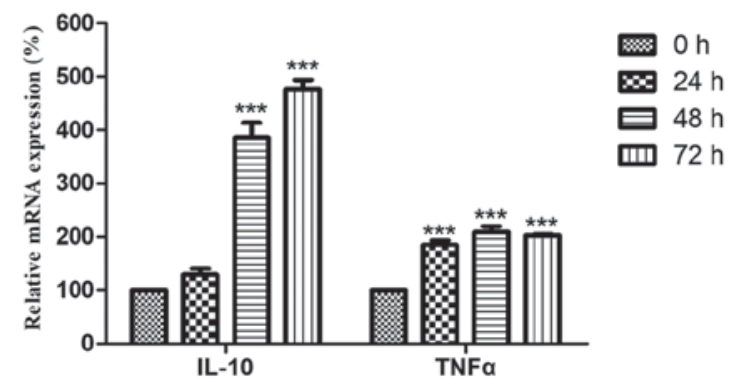

Figure 2. Relative mRNA expression levels of $I L-10, I L-17 A$, and $T N F \alpha$ in (A) U937 cells; (B) $I L-2, I L-10$, and $T N F \alpha$ in HL-60 cells; and (C) $I L-10$ and $T N F \alpha$ in KG-1a cells treated with $0.1 \mu \mathrm{g} / \mathrm{ml}$ PM2.5 for 24,48 , or $72 \mathrm{~h}$. mRNA expression levels are relative to actin $\beta$. Data are presented as the means \pm standard deviations of three identical experiments with four replicates each. ${ }^{* *} \mathrm{P}<0.005,{ }^{* * *} \mathrm{P}<0.0005 \mathrm{vs}$. $0 \mathrm{~h}$. IL, interleukin; TNF, tumor necrosis factor; PM2.5, particulate matter with diameter $\leq 2.5 \mu \mathrm{m}$.
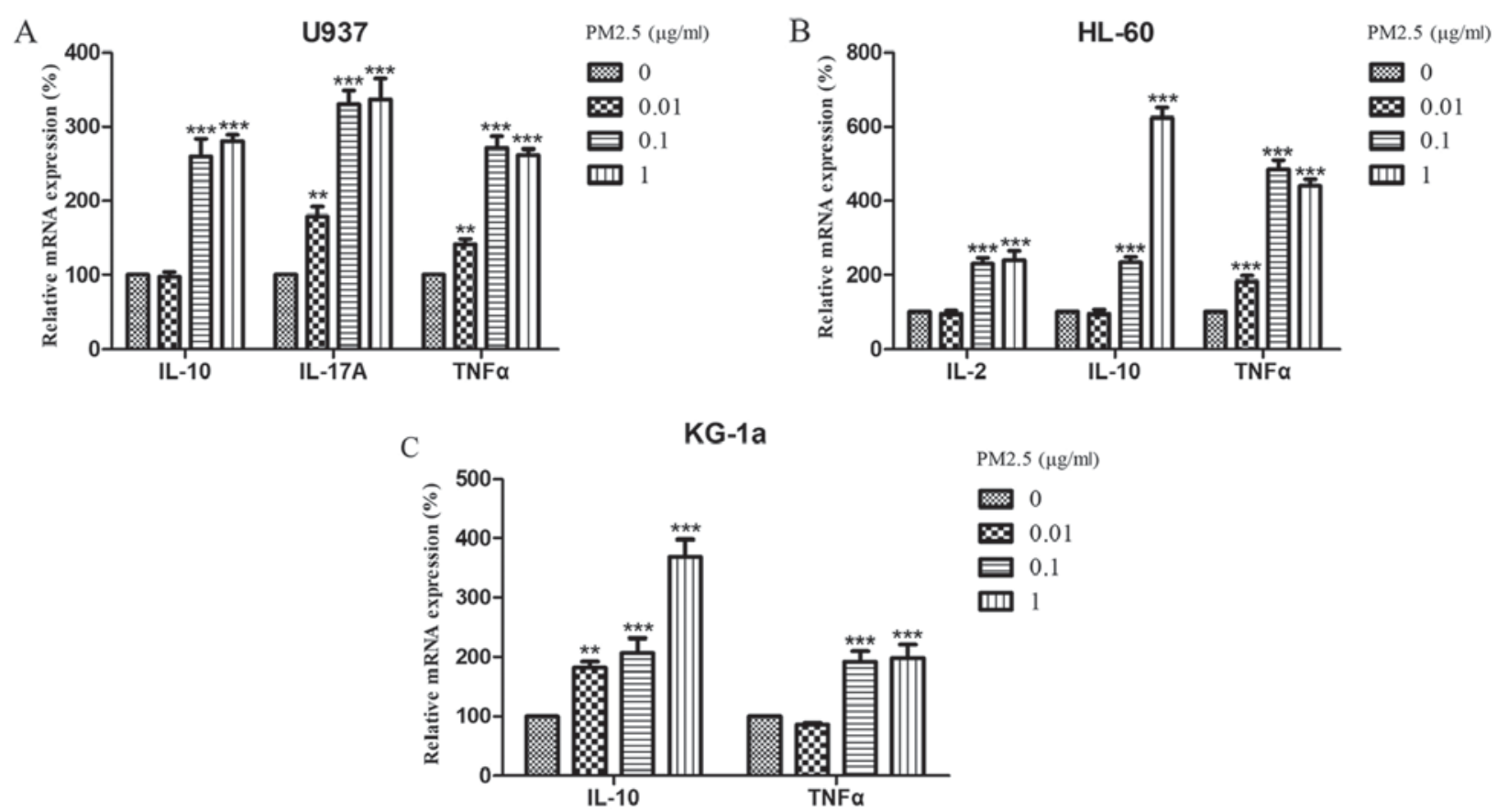

Figure 3. Relative mRNA expression levels of $I L-10$, IL-17A, and TNF $\alpha$ in (A) U937 cells; (B) $I L-2, I L-10$, and $T N F \alpha$ in HL-60 cells; and (C) $I L-10$ and $T N F \alpha$ in KG-1a cells treated with $0,0.01,0.1$, or $1 \mu \mathrm{g} / \mathrm{ml}$ PM2.5 for $72 \mathrm{~h}$. mRNA expression levels are relative to actin $\beta$. Data are presented as the means \pm standard deviations of three identical experiments with four replicates each. ${ }^{* *} \mathrm{P}<0.005,{ }^{* * * *} \mathrm{P}<0.0005$ vs. $0 \mu \mathrm{g} / \mathrm{ml}$. IL, interleukin; TNF, tumor necrosis factor; PM2.5, particulate matter with diameter $\leq 2.5 \mu \mathrm{m}$.

$\mathrm{CD}^{+} \mathrm{T}$ cells, also known as helper $\mathrm{T}$ cells, are divided into three classes: Th1, Th2, and Th17, according to their different cytokine secretion patterns. The differentiation of Th1 and Th2 cells is influenced by local environmental cytokines, and these two groups complement or antagonize each other to regulate immune functions.

$I L-2$ is a Th1 cytokine that is indispensable in immune system regulation. $I L-2$ is secreted by activated $\mathrm{T}$ or natural 
Table III. Content of rat serum cell factors after raising in exposed and clean chambers for 6 weeks.

\begin{tabular}{|c|c|c|c|c|c|c|c|c|c|c|}
\hline \multirow[b]{2}{*}{ Cell factors } & \multirow[b]{2}{*}{ Chamber } & \multicolumn{8}{|c|}{ Content $(\mathrm{pg} / \mathrm{ml})$ in each rat } & \multirow[b]{2}{*}{ P-value } \\
\hline & & 1 & 2 & 3 & 4 & 5 & 6 & 7 & 8 & \\
\hline \multirow[t]{2}{*}{$I L-2$} & Exposed chamber & 35.38 & 16.18 & 33.35 & 9.6 & 25.42 & 13.61 & 9.6 & 8.71 & 0.33 \\
\hline & Clean chamber & 17.95 & 23.5 & 41.6 & 16.18 & 17.95 & 31.33 & & & \\
\hline \multirow[t]{2}{*}{$I L-10$} & Exposed chamber & 25.53 & 89.42 & 222.9 & 56.52 & 23.3 & 23.3 & 155.46 & 41.05 & 0.79 \\
\hline & Clean chamber & 28.97 & 72.71 & 115.15 & 9.45 & 129.69 & 67.25 & & & \\
\hline \multirow[t]{2}{*}{$I L-17 A$} & Exposed chamber & 3.49 & 5.23 & 5.23 & 8.31 & 19.99 & 10.63 & 3.49 & 6.2 & 0.42 \\
\hline & Clean chamber & 5.23 & 13.13 & 5.23 & 8.31 & 11.86 & 17.15 & & & \\
\hline \multirow[t]{2}{*}{$T N F \alpha$} & Exposed chamber & 1.35 & 2.45 & 2.17 & 3.02 & 3.02 & 2.17 & 1.35 & 1.9 & 0.25 \\
\hline & Clean chamber & 2.73 & 2.45 & 1.9 & 1.9 & 3.02 & 3.62 & & & \\
\hline
\end{tabular}

IL, interleukin; TNF, tumor necrosis factor.

Table IV. Content of rat serum cell factors following raising in exposed and clean chambers for 12 weeks.

\begin{tabular}{|c|c|c|c|c|c|c|c|c|c|c|}
\hline \multirow[b]{2}{*}{ Cell factors } & \multirow[b]{2}{*}{ Chamber } & \multicolumn{8}{|c|}{ Content $(\mathrm{pg} / \mathrm{ml})$ in each rat } & \multirow[b]{2}{*}{ P-value } \\
\hline & & 1 & 2 & 3 & 4 & 5 & 6 & 7 & 8 & \\
\hline \multirow[t]{2}{*}{$I L-2$} & Exposed chamber & 9.6 & 8.71 & 6.78 & 14.45 & 12.78 & 9.6 & 6.78 & 5.92 & 0.01 \\
\hline & Clean chamber & 21.61 & 16.18 & 14.45 & 11.16 & & & & & \\
\hline \multirow[t]{2}{*}{$I L-10$} & Exposed chamber & 14.95 & 82.4 & 59.17 & 22.2 & 10.31 & 17.96 & 28.97 & 39.81 & 0.04 \\
\hline & Clean chamber & 351.6 & 192.02 & 66.11 & 14.95 & & & & & \\
\hline \multirow[t]{2}{*}{$I L-17 A$} & Exposed chamber & 4.33 & 5.23 & 2.7 & 5.23 & 8.31 & 5.23 & 2.7 & 4.33 & 0.08 \\
\hline & Clean chamber & 5.23 & 11.86 & 6.2 & 6.2 & & & & & \\
\hline \multirow[t]{2}{*}{$T N F \alpha$} & Exposed chamber & 1.9 & 1.68 & 1.68 & 1.51 & 2.17 & 1.9 & 1.68 & 1.9 & 0.68 \\
\hline & Clean chamber & 1.9 & 1.68 & 1.68 & 2.17 & & & & & \\
\hline
\end{tabular}

IL, interleukin; TNF, tumor necrosis factor.

killer (NK) cells by autocrine or paracrine secretion, and serves an important role in the activation and maintenance of the immune response and in the promotion of lymphocyte development. Numerous studies have confirmed that $I L-2$ induces NK cells and enhances their antitumor activity (24,25). The application of $I L-2$ as an antitumor drug in the clinical treatment of patients with AML began in the 1980s (26). In the present study, it was revealed that $I L-2$ levels increased in a time- and concentration-dependent manner in HL-60 cells treated with PM2.5, but was not detected in U937 or KG-1a cells. In rats, IL-2 expression was significantly enhanced after 12 weeks of exposure to PM2.5. These results suggested that PM2.5 may affect different subtypes of AML cells in different ways; thus, there may be multiple complex cytokine networks in vivo.

$I L-10$ is a Th2 cytokine that has multiple pleiotropic effects on immunoregulation and inflammation, and is capable of inhibiting the synthesis of pro-inflammatory cytokines, including interferon- $\gamma, I L-2$, IL-3, TNF $\alpha$ and granulocyte-macrophage colony-stimulating factor, produced by macrophages and Th1 T cells (27-29). Despite the inhibitory effects of $I L-10$ on Th1 cytokines, certain Th1 cells are also able to produce $I L-10$, and a negative feedback pathway is formed when $I L-10$ regulates Th1 cell activation (27). Previous studies have demonstrated that $I L-10$ directly inhibits the proliferation and migration of effector T cells, and blocks the production of associated cytokines, serving an important role in inducing tumor immune escape. When the $I L-10$ content is increased, the killing effect of T cells on tumor cells is markedly inhibited (30-32). Blocking $I L-10$ expression in animal models improves the killing ability of the immune system on tumor cells $(33,34)$. In addition, $I L-10$ has been shown to inhibit $\mathrm{T}$ cells, forming an immunosuppressive environment and inducing tumor immune escape by inhibiting antigen-presenting cells activation (35). In the present study, the mRNA expression levels of $I L-10$ were significantly increased in a time- and concentration-dependent manner following treatment of AML cell lines with PM2.5 solution. Similar results were also obtained in an in vivo experiment; that is, serum $I L-10$ contents were significantly increased in rats exposed to PM2.5 compared with those of unexposed rats after 12 weeks. These 
results demonstrate the potentially carcinogenetic effects of PM2.5 in AML.

$I L-17 A$ is a pro-inflammatory cytokine produced by activated Th17 cells, which function to amplify inflammation, and activate neutrophils to engulf and digest extracellular bacteria and molds by releasing pro-inflammatory cytokines (36). IL-17 and Th17 cells mediate carcinogenesis in rat tumor models and patients with cancer. The mechanisms through which IL-17 and Th17 cells mediate carcinogenesis involve angiogenesis and the induction of cytokines in the tumor microenvironment, which promotes tumor growth (37-40). Several studies have demonstrated that IL-17 induces IL- 6 production, and IL- 6 activates the signal transducer and activator of transcription 3 pathway, which then upregulates the expression of prosurvival and angiogenic genes to modulate tumor angiogenesis (41-45). The tumor promoting effects of IL-17 and Th1 exist in various types of common tumors (40,46-48). Wu et al (49) demonstrated that Th17 cells were significantly increased in the peripheral blood of patients with AML compared with that in normal healthy individuals. In addition, IL-17 content increased as the number of Th17 cells increased, resulting in promotion of bone marrow cell proliferation and inhibition of immune function. Additionally, the slow growth of $T N F \alpha$ in the tumor microenvironment enhanced the recruitment of IL-17-dependent bone marrow cells and promoted tumor development. In the present study, the mRNA expression of $I L-17 A$ was significantly increased in U937 AML cells a time- and concentration-dependent manner following treatment with PM2.5 solution; however, the $I L-17 A$ content in HL-60 and KG-1a cells was below the detection range. Thus, these findings indicated that different mechanisms mediated the effects of PM2.5 on AML cells. The in vivo experiment revealed no significant increases in exposed rats compared with unexposed rats after 6 or 12 weeks, indicating that the mechanisms through which PM2.5 affected AML differed in vitro and in vivo. However, further studies with increased numbers of animals are required to confirm these findings.

$T N F \alpha$, which is also a Th1 cytokine, is produced ectopically by malignant and immune cells in the tumor-associated microenvironment, creating a tumor-supportive inflammatory niche that modulates the development and progression of malignant disease (50). TNF $\alpha$ is produced by various types of leukemia cells (51-55). In several clinical studies, a positive association between the expression levels of $T N F \alpha$ and adverse clinical parameters in leukemia was observed (53-57) In AML, high levels of $T N F \alpha$ expression are associated with greater fatigue and poorer quality of life (58). Previous studies have revealed that $T N F \alpha$ activates nuclear factor $\kappa \mathrm{B}$ and c-Jun N-terminal kinase/activator protein-1 to exert anti-apoptotic and proproliferative effects in leukemia cells, thereby facilitating leukemia cell survival and progression (32-34, 59-61). In the current study, $T N F \alpha$ levels were significantly increased in U937 and HL-60 cells in a time- and concentration-dependent manner following PM2.5 treatment. In KG-1a cells, $T N F \alpha$ levels were also increased, although the time- and concentration-dependent effects were not as evident. This in vitro experiment reflects the potential ability of PM2.5 to promote the occurrence and development of leukemia by regulating intracellular $T N F \alpha$. In vivo, significant changes in $T N F \alpha$ expression were not observed after 6 or 12 weeks of treatment with PM2.5, further supporting that there may be different mechanisms mediating the effects of PM2.5 on AML in vitro and in vivo. However, again, further studies with greater numbers of animals are required.

\section{Acknowledgements}

The authors would like to thank Dr Xiaokun Geng and Mr Longfei Guan (China-America Institute of Neuroscience, Beijing Luhe Hospital, Capital Medical University, Beijing, China) for their valuable technical assistance with the animal experiments.

\section{Funding}

The present study was supported by the Air Pollution Subject of Science Committee of Tongzhou District (grant no. CK2016KJ035).

\section{Availability of data and materials}

The datasets used and/or analyzed during the current study are available from the corresponding author on reasonable request.

\section{Authors' contributions}

TC performed the cell and animal experiments of the present study and analyzed the obtained data. JZ and $\mathrm{HuZ}$ interpreted the data. YuZ, YoZ and XZ helped TC to perform the animal experiments. DZ and YF helped with the animal experiments and participated in writing the manuscript. HeZ was a major contributor to the idea of the study and participated in writing the manuscript.

\section{Ethics approval and consent to participate}

The present study was approved by Ethics Committee of Beijing Luhe Hospital Affiliated to Capital Medical University (Beijing, China).

\section{Consent for publication}

Not applicable.

\section{Competing interests}

The authors declare they have no competing interests.

\section{References}

1. Henriquez G and Urrea C: Association between air pollution and emergency consultations for respiratory diseases. Rev Med Chil 145: 1371-1377, 2017 (In Spanish).

2. Rabiei K, Hosseini SM, Sadeghi E, Jafari-Koshki T, Rahimi M, Shishehforoush M, Lahijanzadeh A, Sadeghian B, Moazam E, Mohebi MB, et al: Air pollution and cardiovascular and respiratory disease: Rationale and methodology of CAPACITY study. ARYA Atheroscler 13: 264-273, 2017.

3. Trnjar K, Pintarić S, Mornar Jelavić M, Nesek V, Ostojić J, Pleština S, Śikić A and Pintarić H: Correlation between occurrence and deterioration of respiratory diseases and air pollution within the legally permissible limits. Acta Clin Croat 56: 210-217, 2017. 
4. Faridi S, Shamsipour M, Krzyzanowski M, Künzli N, Amini H, Azimi F, Malkawi M, Momeniha F, Gholampour A, Hassanvand MS and Naddafi K: Long-term trends and health impact of PM2.5 and O3 in Tehran, Iran, 2006-2015. Environ Int 114: 37-49, 2018.

5. Kolpakova AF, Sharipov RN and Kolpakov FA: Air pollution by particulate matter as the risk factor for the cardiovascular diseases. Gig Sanit 96: 133-137, 2017.

6. Stachyra K, Kiepura A and Olszanecki R: Air pollution and atherosclerosis-a brief review of mechanistic links between atherogenesis and biological actions of inorganic part of particulate matter. Folia Med Cracov 57: 37-46, 2017.

7. Hüls A, Vierkötter A, Sugiri D, Abramson MJ, Ranft U, Krämer U and Schikowski T: The role of air pollution and lung function in cognitive impairment. Eur Respir J 51: 1701963, 2018

8. Kim H, Kim J, Kim S, Kang SH, Kim HJ, Kim H, Heo J, Yi SM, Kim K, Youn TJ and Chae IH: Cardiovascular effects of long-term exposure to air pollution: A population-based study with 900845 person-years of follow-up. J Am Heart Assoc 6: e007170, 2017.

9. Brunekreef B and Holgate ST: Air pollution and health. Lancet 360: 1233-1242, 2002.

10. Li R, Kou X, Geng H, Xie J, Tian J, Cai Z and Dong C: Mitochondrial damage: An important mechanism of ambient PM2.5 exposure-induced acute heart injury in rats. J Hazard Mater 287: 392-401, 2015.

11. Wang $\mathrm{C}, \mathrm{Tu} \mathrm{Y}, \mathrm{Yu} \mathrm{Z}$ and $\mathrm{Lu} \mathrm{R}$ : PM2.5 and cardiovascular diseases in the elderly: An overview. Int J Environ Res Public Health 12: 8187-8197, 2015.

12. Dabass A, Talbott EO, Venkat A, Rager J, Marsh GM, Sharma RK and Holguin F: Association of exposure to particulate matter (PM2.5) air pollution and biomarkers of cardiovascular disease risk in adult NHANES participants (2001-2008). Int J Hyg Environ Health 219: 301-310, 2016.

13. Yang A, Janssen NA, Brunekreef B, Cassee FR, Hoek G and Gehring U: Children's respiratory health and oxidative potential of PM2.5: The PIAMA birth cohort study. Occup Environ Med 73: 154-160, 2016

14. Brosselin P, Rudant J, Orsi L, Leverger G, Baruchel A, Bertrand Y, Nelken B, Robert A, Michel G, Margueritte G, et al: Acute childhood leukaemia and residence next to petrol stations and automotive repair garages: The ESCALE study (SFCE). Occup Environ Med 66: 598-606, 2009.

15. Steffen C, Auclerc MF, Auvrignon A, Baruchel A, Kebaili K, Lambilliotte A, Leverger G, Sommelet D, Vilmer E, Hémon D and Clavel J: Acute childhood leukaemia and environmental exposure to potential sources of benzene and other hydrocarbons; a case-control study. Occup Environ Med 61: 773-778, 2004.

16. Raaschou-Nielsen O, Ketzel M, Harbo Poulsen A and Sørensen M: Traffic-related air pollution and risk for leukaemia of an adult population. Int J Cancer 138: 1111-1117, 2016.

17. Chiarini F, Lonetti A, Evangelisti C, Buontempo F, Orsini E, Evangelisti C, Cappellini A, Neri LM, McCubrey JA and Martelli AM: Advances in understanding the acute lymphoblastic leukemia bone marrow microenvironment: From biology to therapeutic targeting. Biochim Biophys Acta 1863: 449-463, 2016.

18. Kumar B, Garcia M, Murakami JL and Chen CC: Exosomemediated microenvironment dysregulation in leukemia. Biochim Biophys Acta 1863: 464-470, 2016.

19. Jin XT, Chen ML, Li RJ, An Q, Song L, Zhao Y, Xiao H, Cheng L and Li ZY: Progression and inflammation of human myeloid leukemia induced by ambient PM2.5 exposure. Arch Toxicol 90: 1929-1938, 2016

20. Livak KJ and Schmittgen TD: Analysis of relative gene expression data using real-time quantitative PCR and the 2(-delta delta C(T)) method. Methods 25: 402-408, 2001.

21. Castro-Jimenez MÁ and Orozco-Vargas LC: Parental exposure to carcinogens and risk for childhood acute lymphoblastic leukemia, Colombia, 2000-2005. Prev Chronic Dis 8: A106, 2011.

22. McHale CM, Zhang L and Smith MT: Current understanding of the mechanism of benzene-induced leukemia in humans: Implications for risk assessment. Carcinogenesis 33: 240-252, 2012.

23. Filippini T, Heck JE, Malagoli C, Del Giovane C and Vinceti $M$ A review and meta-analysis of outdoor air pollution and risk of childhood leukemia. J Environ Sci Health C Environ Carcinog Ecotoxicol Rev 33: 36-66, 2015.

24. Sharma A, Rajappa M, Satyam A and Sharma M: Cytokines (TH1 and TH2) in patients with advanced cervical cancer undergoing neoadjuvant chemoradiation: Correlation with treatment response. Int J Gynecol Cancer 19: 1269-1275, 2009.
25. Becker Y: Molecular immunological approaches to biotherapy of human cancers-a review, hypothesis and implications Anticancer Res 26: 1113-1134, 2006.

26. Min G: Interleukin-2 and its application in the treatment of patients with acute myelogenous leukemia. J Leukemia Lymphoma 17: 152-155, 2008 (In Chinese).

27. Shouval DS, Ouahed J, Biswas A, Goettel JA, Horwitz BH, Klein C, Muise AM and Snapper SB: Interleukin 10 receptor signaling: Master regulator of intestinal mucosal homeostasis in mice and humans. Adv Immunol 122: 177-210, 2014.

28. Yang Qing ZL: Interleukin family cytokines and stem cell mobilization. Chin J Comp Med 21: 62-65, 2011 (In Chinese).

29. Lobo-Silva D, Carriche GM, Castro AG, Roque S and Saraiva M: Balancing the immune response in the brain: IL-10 and its regulation. J Neuroinflammation 13: 297, 2016.

30. de Waal Malefyt R, Haanen J, Spits H, Roncarolo MG, te Velde A, Figdor C, Johnson K, Kastelein R, Yssel H and de Vries JE: Interleukin-10 (IL-10) and viral IL-10 strongly reduce antigen-specific human $\mathrm{T}$ cell proliferation by diminishing the antigen-presenting capacity of monocytes via downregulation of class II major histocompatibility complex expression. J Exp Med 174: 915-924, 1991.

31. Mumm JB, Emmerich J, Zhang X, Chan I, Wu L, Mauze S, Blaisdell S, Basham B, Dai J, Grein J, et al: IL-10 elicits IFN $\gamma$-dependent tumor immune surveillance. Cancer Cell 20: 781-796, 2011.

32. Wang Y, Ma Y, Fang Y, Wu S, Liu L, Fu D and Shen X: Regulatory T cell: A protection for tumour cells. J Cell Mol Med 16: 425-436, 2012.

33. Tanikawa T, Wilke CM, Kryczek I, Chen GY, Kao J, Núñez G and Zou W: Interleukin-10 ablation promotes tumor development, growth, and metastasis. Cancer Res 72: 420-429, 2012.

34. Mocellin S, Marincola F, Rossi CR, Nitti D and Lise M: The multifaceted relationship between IL-10 and adaptive immunity: Putting together the pieces of a puzzle. Cytokine Growth Factor Rev 15: 61-76, 2004.

35. Mittal SK and Roche PA: Suppression of antigen presentation by IL-10. Curr Opin Immunol 34: 22-27, 2015.

36. Han L, Yang J, Wang X, Li D, Lv L and Li B: Th17 cells in autoimmune diseases. Front Med 9: 10-19, 2015.

37. Housseau F, Wu S, Wick EC, Fan H, Wu X, Llosa NJ, Smith KN, Tam A, Ganguly S, Wanyiri JW, et al: Redundant innate and adaptive sources of IL17 production drive colon tumorigenesis. Cancer Res 76: 2115-2124, 2016.

38. Patil RS, Shah SU, Shrikhande SV, Goel M, Dikshit RP and Chiplunkar SV: IL17 producing $\gamma \delta$ T cells induce angiogenesis and are associated with poor survival in gallbladder cancer patients. Int J Cancer 139: 869-881, 2016.

39. Benevides L, da Fonseca DM, Donate PB, Tiezzi DG De Carvalho DD, de Andrade JM, Martins GA and Silva JS: IL17 promotes mammary tumor progression by changing the behavior of tumor cells and eliciting tumorigenic neutrophils recruitment. Cancer Res 75: 3788-3799, 2015

40. Numasaki M, Fukushi J, Ono M, Narula SK, Zavodny PJ, Kudo T, Robbins PD, Tahara H and Lotze MT: Interleukin-17 promotes angiogenesis and tumor growth. Blood 101: 2620-2627, 2003.

41. Lee EJ, Park HJ, Lee IJ, Kim WW, Ha SJ, Suh YG and Seong J: Inhibition of IL-17A suppresses enhanced-tumor growth in low dose pre-irradiated tumor beds. PLoS One 9: e106423, 2014.

42. Ju X, Ijaz T, Sun H, Ray S, Lejeune W, Lee C, Recinos A III, Guo DC, Milewicz DM, Tilton RG and Brasier AR: Interleukin-6-signal transducer and activator of transcription-3 signaling mediates aortic dissections induced by angiotensin II via the T-helper lymphocyte 17-interleukin 17 axis in C57BL/6 mice. Arterioscler Thromb Vasc Biol 33: 1612-1621, 2013.

43. Kumar P. Natarajan K and Shanmugam N: High glucose driven expression of pro-inflammatory cytokine and chemokine genes in lymphocytes: Molecular mechanisms of IL-17 family gene expression. Cell Signal 26: 528-539, 2014.

44. Chen XW and Zhou SF: Inflammation, cytokines, the IL-17/IL-6/STAT3/NF- $\kappa$ B axis, and tumorigenesis. Drug Des Devel Ther 9: 2941-2946, 2015.

45. Hu Z, Luo D, Wang D, Ma L, Zhao Y and Li L: IL-17 activates the IL-6/STAT3 signal pathway in the proliferation of hepatitis B virus-related hepatocellular carcinoma. Cell Physiol Biochem 43: 2379-2390, 2017

46. Zhang JP, Yan J, Xu J, Pang XH, Chen MS, Li L, Wu C, Li SP and Zheng L: Increased intratumoral IL-17-producing cells correlate with poor survival in hepatocellular carcinoma patients. J Hepatol 50: 980-989, 2009. 
47. Du JW, Xu KY, Fang LY and Qi XL: Interleukin-17, produced by lymphocytes, promotes tumor growth and angiogenesis in a mouse model of breast cancer. Mol Med Rep 6: 1099-1102, 2012.

48. Mucida D, Park Y, Kim G, Turovskaya O, Scott I, Kronenberg M and Cheroutre H: Reciprocal TH17 and regulatory T cell differentiation mediated by retinoic acid. Science 317: 256-260, 2007.

49. Wu C, Wang S, Wang F, Chen Q, Peng S, Zhang Y, Qian J, Jin J and $\mathrm{Xu} \mathrm{H}$ : Increased frequencies of $\mathrm{T}$ helper type 17 cells in the peripheral blood of patients with acute myeloid leukaemia. Clin Exp Immunol 158: 199-204, 2009.

50. Waters JP, Pober JS and Bradley JR: Tumour necrosis factor and cancer. J Pathol 230: 241-248, 2013.

51. Gallipoli P, Pellicano F, Morrison H, Laidlaw K, Allan EK, Bhatia R, Copland M, Jørgensen HG and Holyoake TL: Autocrine TNF- $\alpha$ production supports CML stem and progenitor cell survival and enhances their proliferation. Blood 122: 3335-3339, 2013.

52. Sanchez-Correa B, Bergua JM, Campos C, Gayoso I, Arcos MJ, Bañas H, Morgado S, Casado JG, Solana R and Tarazona R: Cytokine profiles in acute myeloid leukemia patients at diagnosis: Survival is inversely correlated with IL-6 and directly correlated with IL-10 levels. Cytokine 61: 885-891, 2013.

53. Potapnev MP, Petyovka NV, Belevtsev MV, Savitskiy VP and Migal NV: Plasma level of tumor necrosis factor-alpha (TNF-alpha) correlates with leukocytosis and biological features of leukemic cells, but not treatment response of children with acute lymphoblastic leukemia. Leuk Lymphoma 44: 1077-1079, 2003.

54. Foa R, Massaia M, Cardona S, Tos AG, Bianchi A, Attisano C, Guarini A, di Celle PF and Fierro MT: Production of tumor necrosis factor-alpha by B-cell chronic lymphocytic leukemia cells: A possible regulatory role of TNF in the progression of the disease. Blood 76: 393-400, 1990

55. Lech-Maranda E, Grzybowska-Izydorczyk O, Wyka K, Mlynarski W, Borowiec M, Antosik K, Cebula-Obrzut B, Makuch-Lasica H, Nowak G, Klimkiewicz-Wojciechowska G, et al: Serum tumor necrosis factor-alpha and interleukin-10 levels as markers to predict outcome of patients with chronic lymphocytic leukemia in different risk groups defined by the IGHV mutation status. Arch Immunol Ther Exp (Warsz) 60: 477-486, 2012
56. Ferrajoli A, Keating MJ, Manshouri T, Giles FJ, Dey A, Estrov Z, Koller CA, Kurzrock R, Thomas DA, Faderl S, et al: The clinical significance of tumor necrosis factor-alpha plasma level in patients having chronic lymphocytic leukemia. Blood 100: 1215-1219, 2002 .

57. Kupsa T, Vasatova M, Karesova I, Zak P and Horacek JM: Baseline serum levels of multiple cytokines and adhesion molecules in patients with acute myeloid leukemia: Results of a pivotal trial. Exp Oncol 36: 252-257, 2014.

58. Fung FY, Li M, Breunis H, Timilshina N, Minden MD and Alibhai SM: Correlation between cytokine levels and changes in fatigue and quality of life in patients with acute myeloid leukemia. Leuk Res 37: 274-279, 2013.

59. Hess P, Pihan G, Sawyers CL, Flavell RA and Davis RJ: Survival signaling mediated by c-Jun $\mathrm{NH}(2)$-terminal kinase in transformed B lymphoblasts. Nat Genet 32: 201-205, 2002.

60. Tsai HJ, Kobayashi S, Izawa K, Ishida T, Watanabe T, Umezawa K, Lin SF and Tojo A: Bioimaging analysis of nuclear factor- $\kappa \mathrm{B}$ activity in Philadelphia chromosome-positive acute lymphoblastic leukemia cells reveals its synergistic upregulation by tumor necrosis factor- $\alpha$-stimulated changes to the microenvironment. Cancer Sci 102: 2014-2021, 2011.

61. Volk A, Li J, Xin J, You D, Zhang J, Liu X, Xiao Y, Breslin P, $\mathrm{Li} Z$, Wei W, et al: Co-inhibition of NF- $\mathrm{KB}$ and JNK is synergistic in TNF-expressing human AML. J Exp Med 211: 1093-1108, 2014. 